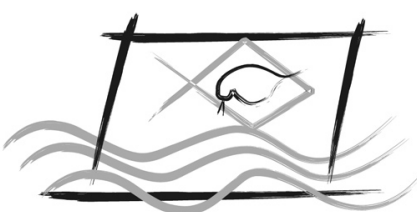

ECOTOX - BRASIL

\title{
Evaluation five years after a Refinary Oil Spill in freshwater wetland - Paraná State, Southern of Brazil
}

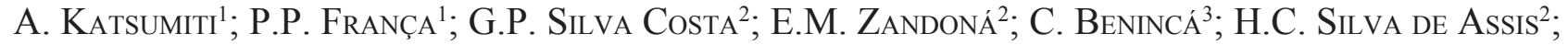 \\ M.M. Cestari ${ }^{3}$; J. Maschio ${ }^{1}$; M.A.F. Randi ${ }^{1}$; C.A. Silva ${ }^{2}$; H.Roche ${ }^{4} \&$ C.A. Oliveira Ribeiro ${ }^{1}$
}

${ }^{1}$ Departamento de Biologia Celular, ${ }^{2}$ Departamento de Farmacologia, ${ }^{3}$ Departamento de Genética. Universidade Federal do Paraná. Cx. Postal 19031, CEP: 81.531-990, Curitiba, PR, Brasil.

${ }^{4}$ Laboratoire d'Ecotoxicologie, Departement d'Ecologie Systématique et Evolution Université Paris-Sud XI, ESE UMR 8079 , Bât 362 F91405 Orsay Cedex, France.

(Received August 11, 2010; Accept September 29, 2011)

\begin{abstract}
In order to evaluate the Getúlio Vargas refinery oil spill - 2000, Paraná State - Brazil the presence of PAHs in the sediment, PAHs bioavailability through bile chemical analysis and biochemical and morphological biomarkers were investigated in a native fish species Hyphessobrycon reticulates. The histophatological parameters were also considered to another native species Phalloceros caudimaculatus. Sediment analysis showed the presence of 5-6 rings PAHs on the surface layer and 2-3 rings PAHs in the deepest sediment showing that oil is still accumulated in sediment, and its bioavailability is confirmed by the accumulation of PAHs in bile. Lipid peroxidation, catalase (CAT), GST and cholinesterase activities indicated respectively oxidative stress in liver of $H$. reticulatus and neurotoxicity, also evidenced by genotoxic and histopathological damages. Despite of the occurrence of other pollutants not identified in the current study, the data presented here may suggest that 5 years after the accident animals as fish can be still affected by hydrocarbons and PAHs presented in the sediment. Concluding, studies must be done to confirm that with a more sophisticated chemical analysis, but this work is the only study realized after the accident. We strongly suggest a new study to compare and verify if still there is risk to biota
\end{abstract}

Keywords: Biomarkers, bioavailability, freshwater ecosystems, oil spills, PAHs.

\section{INTRODUCTION}

Approximately twelve years ago, about 4.0 millions liters of crude oil spilled from Getúlio Vargas refinery (UN-REPAR/ PETROBRAS) situated at the industrial complex of Araucaria - Parana State, south of Brazil (Fig. 1).

Spilled oil affected around $2,250 \mathrm{~m}^{2}$ of a freshwater wetland denominated Arroio Saldanha and more than 50 kilometers of the river courses of Barigui and Iguaçu rivers (Bastos Neto et al., 2001). The Iguaçu hydrographic basin is considered one of the most important in the south of Brazil due to human water supply and its rich biodiversity with many endemic species (Zawadzki et al., 1999). The construction of small oil barriers in the Arroio Saldanha streams was efficient to avoid oil dispersion but critical for the contamination of the area due to the oil retention. According to Meniconi et al. (2002) only $30 \%$ of the spilled oil reached Bariguí and Iguaçu Rivers, and of the total retained oil, only $25 \%$ was removed from Arroio Saldanha.

Environmental factors tends to alter the composition of spilled oil along time and biological factors present in soil, water and sediment tend to alter the molecules from oil spills, making hard to predict precisely the composition of the residual oil and the biological consequences (Pedrozo

*Corresponding author: Cristiano V. M. Araújo; e-mail: cristiano.araujo@icman.csic.es 


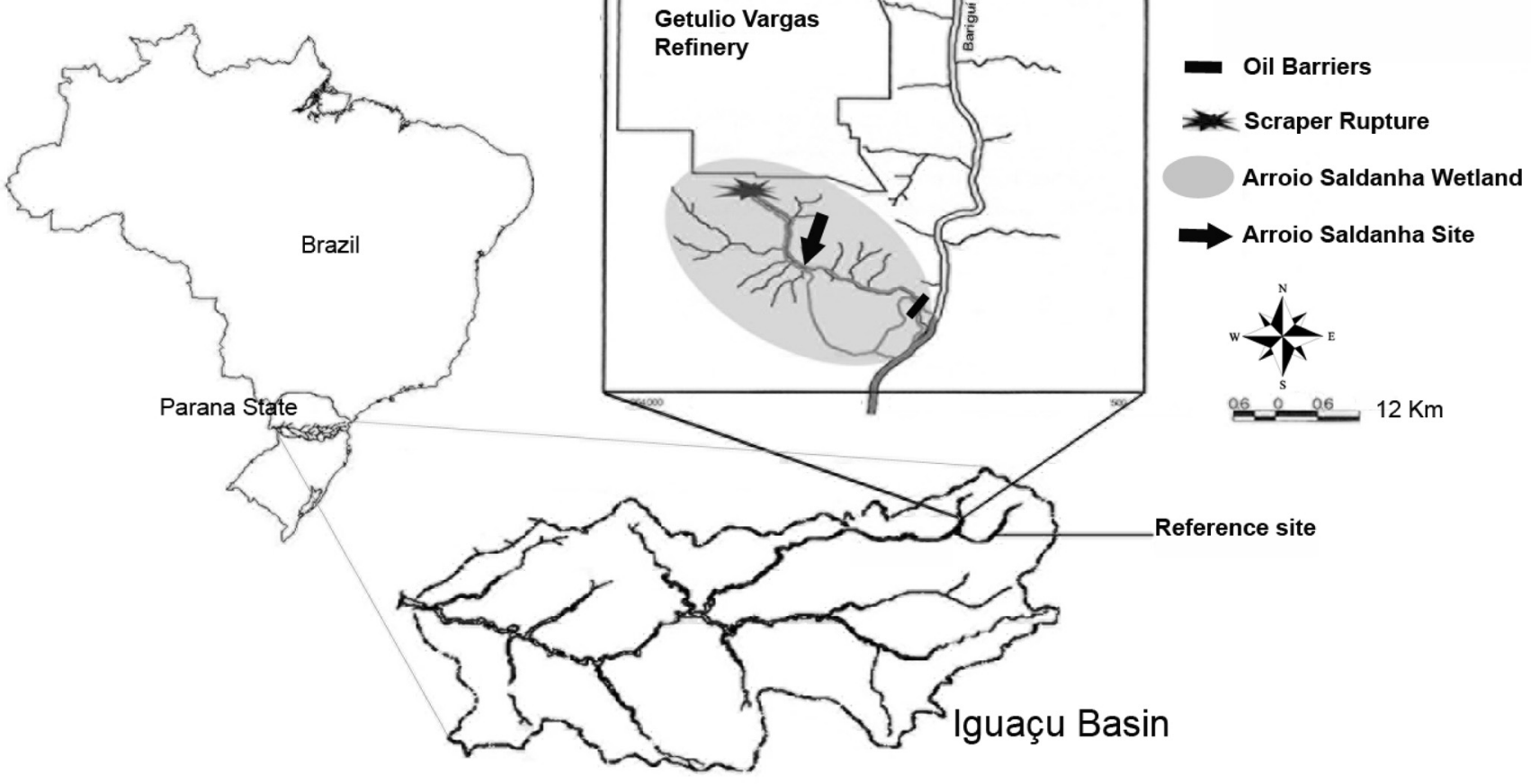

Figure 1 - Map of the studied area in Araucária city, Paraná State - South of Brazil.

et al., 2002). Due to the toxicity to aquatic organisms and the persistence of some hydrocarbon compounds in the environment, the consequences of accidents involving oil spills have been more investigated in the last years. Biomarkers are frequently reported as an efficient tool to evaluate the risk assessment of hydrocarbons in oil spill (Jewett et al., 2002; Marty et al., 2003; Kammerer et al., 2004; Carls et al., 2001, 2004; Marigómez et al., 2006). After the Aegean Sea oil spill in Galician coast, significant levels of lipid peroxidation in digestive glands of mussels were related with the increase of PAHs in the tissues (Solé et al., 1996; Porte et al., 2000). Increases in DNA damage were found in different tissues of fishes after Sea Empress oil spill in South West Wales (Lyons et al., 1997; Harvey et al., 1999). In the Ligurian Sea, eight years after the Haven oil spill Pietrapiana et al., (2002) found genotoxic effects of the residual oil. Marigómez et al. (2006) reported morphological effects and lysosomal enlargement in fish and mussel species from Biscay Bay after the Prestige oil spill. After the Exxon Valdez oil spill in Prince William Sound, acute (Khan \& Nag, 1993; Marty et al. 1999) and chronic (Jewett et al. 2002; Hugget et al., 2003; Marty et al., 2003) histological damages were found in fish.

The aim of the present work was to evaluate the longterm impacts of the Getulio Vargas Refinery oil spill using chemical analysis of PAHs in sediment, and through the study of biochemical and genetic biomarkers five years after the oil spill. In addition, histophatological analyses of sentinel native fish species Hyphessobrycon reticulatus and Phalloceros caudimaculatus were conducted to assess biological effects of chronic exposure to the oil spill. To assess bioavailability of residual hydrocarbons it was performed a short term bioassay (96h) with Astyanax sp. Exposed to Arroio Saldanha water to estimate PAH metabolites in bile.

\section{MATERIALS AND METHODS}

\section{Animals and Sampling}

Hyphessobrycon reticulatus (Characidae, Tetragonopterinae) is a small sub-tropical benthopelagic species of freshwater fish widely distributed in Brazilian streams (Gerry, 1977) and Phalloceros caudimaculatus (Poeciliidae, Poeciliinae) is a pelagic species thoroughly distributed along Brazil, Paraguay and Uruguay (Froese \& Pauly, 2006). Astyanax sp. is a freshwater fish species (Family Characidae, Order Characiformes), widely distributed in Brazilian rivers and streams (Gerry, 1977; Godoy, 1975).

Thirty adults individuals of $H$. reticulatus, and 17 larvae and 27 adults individuals of $P$. caudimaculatus were collected in the same site in February 2005 using small bolter, and transported in tanks ( $100 \mathrm{~L})$ with oxygen supply to the Cellular Toxicology Laboratory for biochemical, histopathological and genotoxic studies (Table 1). For biochemical studies samples were frozen $\left(-80^{\circ} \mathrm{C}\right)$ until analysis procedure. The same number of individuals of $H$. reticulatus was used as controls; specimens were obtained from reference site at Park Costa located at Curitiba Municipality. In addition 274 
Table 1 - Numbers of Hyphessobrycon reticulatus and Phalloceros caudimaculatus collected to morphological (light and scanning microscopy), biochemical (cholinesterase, glutathione S-transferase, catalase and lipid peroxidation) and genetic (comet assay and micronucleus test) analyses.

\begin{tabular}{lcccc}
\hline & Analyses & H. reticulatus & \multicolumn{2}{c}{ P. caudimaculatus } \\
\hline & Adults & Adults & Larvae \\
\hline \multirow{3}{*}{$\begin{array}{l}\text { Arroio } \\
\text { Saldanha }\end{array}$} & \begin{tabular}{c} 
Morphological \\
\cline { 2 - 5 }
\end{tabular} & 30 & 15 & 53 \\
\hline genetic & 30 & ne & ne
\end{tabular}

\begin{tabular}{cccc}
\hline Reference & $\begin{array}{c}\text { Biochemical and } \\
\text { genetic }\end{array}$ & 30 & ne
\end{tabular}

ne = not evaluated;

individuals, between adults and young, of $P$. caudimaculatus were collected to investigate external anatomic deformations.

Sixty adults individuals of Astyanax $s p$. were obtained from a pisciculture farm in Araucária Municipality and acclimatized in the laboratory for 15 days before the bioassay experiments, under controlled temperature $\left(22-21^{\circ} \mathrm{C}\right)$ and photoperiod (12h ligh/12h darkness). After 96 hours of exposure the PAH's bioavailability was determinate by bile chemical analysis. During the acclimatization period fish were fed with commercial food daily (Alcon Guppy®), except during the experiments.

\section{Biochemical Procedures}

Cholinesterase (ChE) activity: Muscle tissue was unfrozen and homogenized in ice-cold $0.1 \mathrm{M}$ potassium phosphate buffer in $\mathrm{pH} 7.5$. Homogenates were centrifuged at $10000 \mathrm{x} g$ for $10 \mathrm{~min}$ at $4^{\circ} \mathrm{C}$ for enzyme activity measurement according to Ellmann et al. (1961) adapted for microplates (Silva de Assis, 1998). The enzymatic activity was expressed as nmol. $\min ^{-1} . \mathrm{mg}$ protein ${ }^{-1}$.

Glutathione S-Transferase (GST) activity: Liver tissue was unfrozen and homogenized in ice-cold $0.1 \mathrm{M}$ potassium phosphate buffer, in pH 6.5 for GST and catalase analysis. S9 fraction was obtained from liver of $H$. reticulatus and the global GST activity was determined by measuring the increase in absorbance, using reduced glutathione (GSH) and 1-chloro-2,4dinitrobenzene (CDNB) as substrate according to Keen et al. (1976). The concentration of $1.5 \mathrm{mM}$ GSH and 2.0 mM CDNB was used. The absorbance increase was measured at $340 \mathrm{~nm}$.

Catalase (CAT) activity: S9 fraction was obtained from liver of $H$. reticulatus and CAT activity was assayed spectrophotometrically by measuring the decrease in absorbance of $\mathrm{H}_{2} \mathrm{O}_{2}$ (Aebi, 1984). The concentration of $20 \mathrm{mM} \mathrm{H}_{2} \mathrm{O}_{2}, 50$ $\mathrm{mM}$ Tris buffer, $0.25 \mathrm{mM}$ EDTA, $\mathrm{pH} 8.0,25^{\circ} \mathrm{C}$ was used). The decreasing absorbance was measured at $240 \mathrm{~nm}$.

Lipid Peroxidation (LPO): LPO was determined by FOX (ferrous oxidation-xylenol) assay (Jiang et al., 1991, 1992) with minor modifications. Liver fragments of sacrificed $H$. reticulatus were immediately frozen $\left(-80^{\circ} \mathrm{C}\right)$ and the homogenates centrifuged at $1000 \times \mathrm{g}$ for $10 \mathrm{~min}$ at $4^{\circ} \mathrm{C}$. For the assay, $30 \mu \mathrm{l}$ of supernatant and $270 \mu \mathrm{L}$ of a solution containing $100 \mu \mathrm{M}$ xylenol orange, $25 \mathrm{mM} \mathrm{H}_{2} \mathrm{SO}_{4}, 4 \mathrm{mM}$ BHT (butylated hydroxytoluene) and $250 \mu \mathrm{M} \mathrm{FeSO} \cdot \mathrm{NH}_{4}$ (ammonium ferrous sulfate) in 90\% grade methanol were added to a 96 well microplate. Blanks were prepared by replacing the supernatant for Tris-sucrose buffer. Samples were incubated at room temperature for $30 \mathrm{~min}$ until the reaction is complete and absorbance was measured at $570 \mathrm{~nm}$. To determine the hydroperoxides concentration, it was used the apparent molar extinction coefficient for $\mathrm{H}_{2} \mathrm{O}_{2}$ and cumene hydroperoxide of $4.3 \times 10^{4} \mathrm{M}^{-1} \mathrm{~cm}^{-1}$.

\section{Protein concentration}

Total proteins were quantified in the samples following Bradford (1976). Supernatant $(10 \mu \mathrm{l})$ and $250 \mu \mathrm{L}$ of Bradford reagent ("Coomassie brilliant blue" BG-250) were placed in a 96-well microplate and absorbance was measured at 595 $\mathrm{nm}$. Protein content was calculated through comparison with a standard curve of bovine serum albumin.

\section{Genotoxic Procedures}

Comet Assay: DNA damage (unspecific DNA cleavage) was analyzed by means of the Comet assay (Singh et al., 1988). Hepathocytes of $H$. reticulatus were suspended in $0.5 \%$ low melting point agarose (LMPA), layered onto precoated $1.5 \%$ normal melting point agarose microscope slides and spread with a cover slip. After LMPA solidification, the cover slips were removed and the slides were kept in a cold lysing solution (220 mM NaCl, 9 mM EDTA, 0.9 mM Tris, 1\% Triton X-100 and $10 \%$ DMSO, $0.9 \%$ sodium sarcosianate, $\mathrm{pH} 10.0$ ) for $1 \mathrm{~h}$ at $4{ }^{\circ} \mathrm{C}$. Then, the slides were placed in electrophoresis buffer (300 mM NaOH, $1 \mathrm{mM}$ EDTA, 2\% DMSO, pH>13) for $20 \mathrm{~min}$ to allow DNA unwinding. Electrophoresis was performed at $25 \mathrm{~V}$ and $300 \mathrm{~mA}$ for $20 \mathrm{~min}$. After electrophoresis, the slides were neutralized in $0.4 \mathrm{M}$ Tris $(\mathrm{pH} 7.5)$, fixed in absolute ethanol during $10 \mathrm{~min}$ and stained with ethidium bromide (2 $\left.\mu \mathrm{g} \mathrm{ml}^{-1}\right)$. All procedures were performed under red light. For analyzes, a hundred nuclei per slide were blindly classified by their tail size $(0,1,2,3$ and 4) under a ZEISS Axiophot microscope and scored as follow: Score $=\sum$ (damage class $\mathrm{x}$ percentage of incidence).

Micronucleus Test: It was followed the proposed method by Heddle (1973) and Schmid (1975) with modifications. Blood samples of $H$. reticulatus were obtained from the caudal vein of the specimens and distended on clean slides. After fixation in ethanol for $30 \mathrm{~min}$, slides were left to air-dry and stained with $10 \%$ Giemsa solution for $10 \mathrm{~min}$. Besides the micronucleus (MN) counting, the nuclear alterations (NAs) in erythrocytes of $H$. reticulatus were also registered. Small, nonrefractive, circular or ovoid chromatin bodies showing the same staining pattern as the main nucleus were considered as MN (Al-Sabti \& Metcalfe, 1995). NAs were classified according to Carrasco et al. (1990). From each slide 2000 erythrocytes were scored under $400 \times$ magnification.

Histopathological Procedures morphological analysis adult specimens of $H$. reticulatus and $P$. caudimaculatus were collected to light microscopy (gills and liver) and Scanning Electron Microscopy (SEM) (gills) analyses, and larvae of $P$. 
caudimaculatus were removed from the females' peritoneal cavity to internal histological evaluation (liver, gills, kidney, thymus, pseudobranchi and retina).

Light microscopy: Gills and liver from both species and larvae samples of $P$. caudimaculatus were preserved in Alfac fixative solution $(16 \mathrm{~h})$ dehydrated in a graded series of ethanol and embedded in Paraplast Plus resin $\left(\right.$ Sigma $\left.{ }^{\circledR}\right)$. The sliced sections $(5 \mu \mathrm{m})$ were stained in Hematoxilin/Eosin and observed under a ZEISS Axiophot photomicroscope according to Akaishi et al. (2004).

Scanning electron microscopy (SEM): Gills were fixed in 3\% glutaraldehyde, $0.1 \mathrm{M}$ sodium cacodylate, $\mathrm{pH} 7.2$ - 7.4, washed in $0.1 \mathrm{M}$ sodium cacodylate buffer, dehydrated in graded series of ethanol (Merck $\left.{ }^{\circledR}\right)$, and critical point with $\mathrm{CO}_{2}$. The samples were observed using a JEOL JSM-6360LV scanning electron microscope according to Alves Costa et al. (2007).

\section{PAH's Bioavailability Experiment}

Sixty adult individuals of Astyanax sp. were exposed to water collected in the same site used in field studies. Water was transported to the bioassays laboratory facility of the Aquatoxi research group (Aquatoxi/UFPR) and distributed in six 15 liters glass aquaria (two 100\% and two 50\% diluted in reconstituted water) according with Akaishi et al. (2004) with 10 individuals per aquarium. As experiment control, two aquaria with reconstituted water were used. After 96 hours exposure, bile was collected from individual animals, pooled ( 3 animals per pool) and frozen at $-76^{\circ} \mathrm{C}$ to be analyzed as described below.

\section{Sediment and Bile Chemical Analyses}

Sediment and bile chemical analysis were performed following the same fluorimetric protocol (Aas et al. 2000), differing in the pre-treatment of the samples. Sediment cores (30 $\mathrm{cm}$ depth) were collected in duplicate from the principal stream of the Arroio Saldanha and frozen $\left(-20^{\circ} \mathrm{C}\right)$ until analyses. Sediment core was divided in four sub-samples cores $(7.5 \mathrm{~cm}$ each) at different depth, dried $\left(45^{\circ} \mathrm{C}\right)$, solubilized in methanol $(48 \%)(1: 600 \mathrm{v} / \mathrm{w})$ and filtered $(0.45 \mu \mathrm{m})$ to fluorimetric

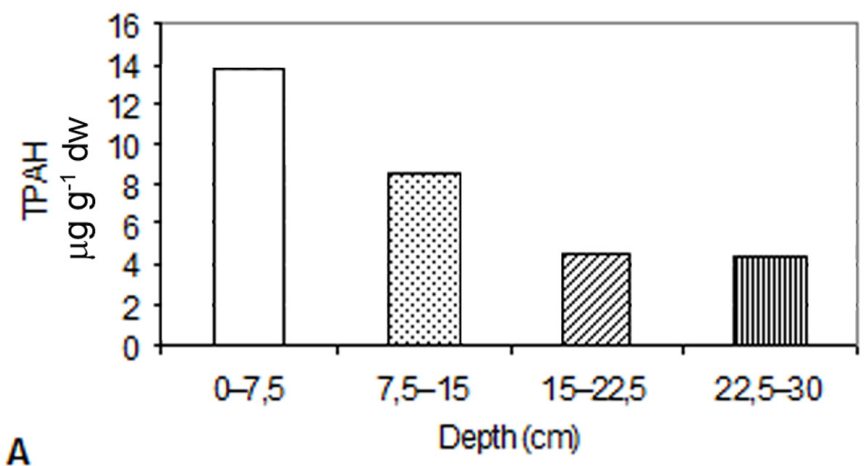

measurements. Bile samples were also diluted in methanol $48 \%(1: 600 \mathrm{v} / \mathrm{v})$. PAHs were detected by fixed wavelength fluorescence performed in a RF-5301 PC Spectrofluorimeter using the 16 PAHs considered priority pollutants by the US Environment Protection Agency (USEPA) as references. The wavelength pairs of excitation/emission used to detect PAHs were: $288 / 330 \mathrm{~nm}$ (2 ringnaphthalene type), 267/309 nm (3 ring phenanthrene type), $334 / 376 \mathrm{~nm}$ (4 ringpyrene type), $364 / 406 \mathrm{~nm}$ (5 ring benzo( $a$ )pyrene type) and 380/422 nm (6 ringbenzo( $g h i)$ perylene type). The bile values were normalized related to proteins content as described above according to Bradford (1976).

In compliance with the protection of human subjects and animal welfare, authors team also assure that the animals used in the experimental design described in the current work were treated in accordance with the guidelines of NIH for care and use of laboratory animals.

\section{Statistics}

Non parametric statistics (Mann-Whitney Test) were used for genotoxic assays. For other assays, normality of data was tested by Kolmogorv-Smirnov test followed by t-test comparing control and exposed animals at $\mathrm{p}<0.05$ (significant difference) and $p<0.001$ (high significant difference). All statistical analyses were conducted with Staview (SAS Institute Cary, NC, USA.).

\section{RESULTS}

In sediment, the majority of PAHs were found in shallow layers (until $15 \mathrm{~cm}$ depth) (Fig. 2A). After $15 \mathrm{~cm}$ depth, higher 5 and 6 aromatic rings concentrations were found $(6$ and $8 \mu \mathrm{g}$ $\left.\mathrm{g}^{-1}\right)$; deepest samples reveled a higher concentration of 2, 3 and 4 aromatic rings $\left(1-3 \mu \mathrm{g} \mathrm{g}^{-1}\right)$ (Fig. 2B). The chemical analysis of PAH's in bile Astyanax sp. exposed to water from Arroio Saldanha wetland revealed that PAHs are still bioavailable in water (Table 2).

From the biochemical analysis, individuals collected in the Arroio Saldanha showed a decrease in the ChE activity (56 \pm 6.59

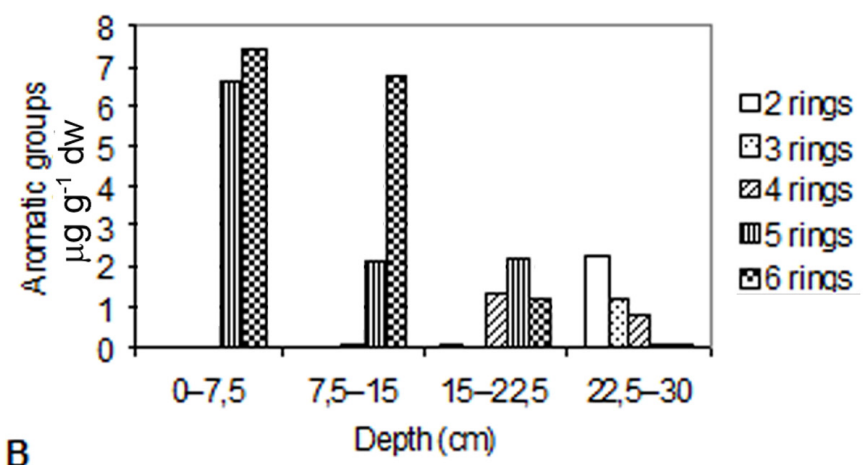

Figure 2 - Profile of the sediment cores dry weight (dw) PAH concentrations from Arroio Saldanha. (A) Total PAHs. (B) Specific aromatic groups (2-6 rings). 2-rings PAHs main include naphthalene; 3-rings PAHs main include acenaphthylene, acenaphthene, fluorene, phenanthrene and anthracene; 4-rings PAHs main include fluoranthene, pyrene, benzo(a)anthracene and chrysene; 5-rings PAHs main include benzo(b)fluoranthene, benzo(k)fluoranthene, benzo(a)pyrene and dibenzo(ah)anthracene; 6-rings PAHs main include indeno(123-cd)pyrene and benzo(ghi)perylene. 
Table 2 - PAHs distribution in bile of Astyanax sp. $\left(\mathrm{mg} \mathrm{kg}^{-1}\right)$ after waterborne exposure ( 96 hours) to water sample from Arroio Saldanha six years after the accident -2005 (pools mean \pm standard desviation).

\begin{tabular}{lcccccc}
\hline & 2 rings & 3 rings & 4 rings & 5 rings & 6 rings & $\sum$ PAHs \\
\hline Control & $1.46 \pm 0.23$ & $2.77 \pm 0.28$ & $2.77 \pm 0.92$ & $4.77 \pm 1.42$ & $0.87 \pm 0.23$ & $12.48 \pm 2.11$ \\
\hline $\begin{array}{l}\text { Arroio } \\
\text { Saldanha }\end{array}$ & $4.53 \pm 0.56$ & $5.30 \pm 0.73$ & $5.42 \pm 0.52$ & $5.58 \pm 0.48$ & $1.09 \pm 0.11$ & $21.94 \pm 2.11$
\end{tabular}

nmol.min ${ }^{-1} \cdot \mathrm{mg}^{-1}$ protein) compared to the control $(75.81 \pm 5.38$ nmol.min ${ }^{-1} \mathrm{mg}^{-1}$ protein) (Fig. 3A). An increase in GST activity was found in individuals from Arroio Saldanha (95.59 \pm 4.16 nmol.min ${ }^{-1} \cdot \mathrm{mg}^{-1}$ protein) compared to individuals from reference site $\left(55.07 \pm 4.43 \mathrm{nmol} \mathrm{min} \mathrm{mg}^{-1} \mathrm{mg}^{-1}\right)$ (Fig. 3B). Animals from Arroio Saldanha did not show any significant differences in CAT activity with respect to individuals from reference site (Fig. $3 \mathrm{C})$. For LPO, an increase in production of lipid hydroperoxides $\left(28.38 \pm 1.25 \mathrm{nmol} \mathrm{mg}^{-1}\right)$ was observed in the hepatic tissue of H. reticulatus from Arroio Saldanha when compared with the reference site (15.64 $\left.\pm 1.22 \mathrm{nmol} \mathrm{mg}^{-1}\right)$ (Fig. 3D).
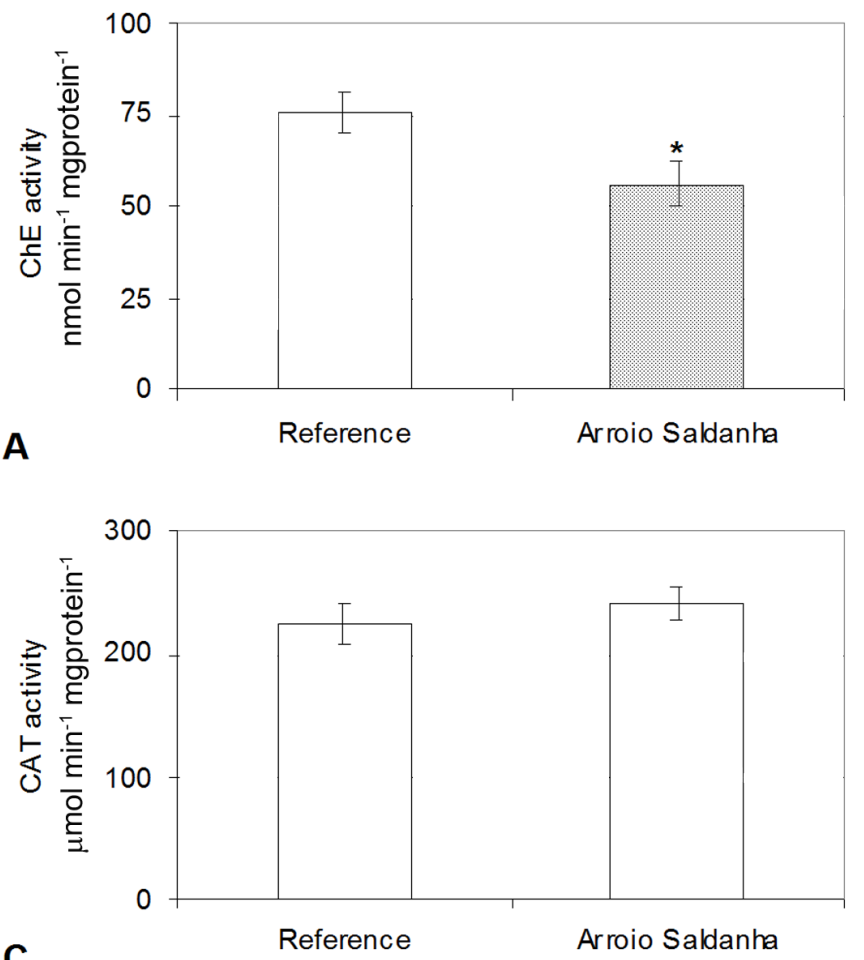

C

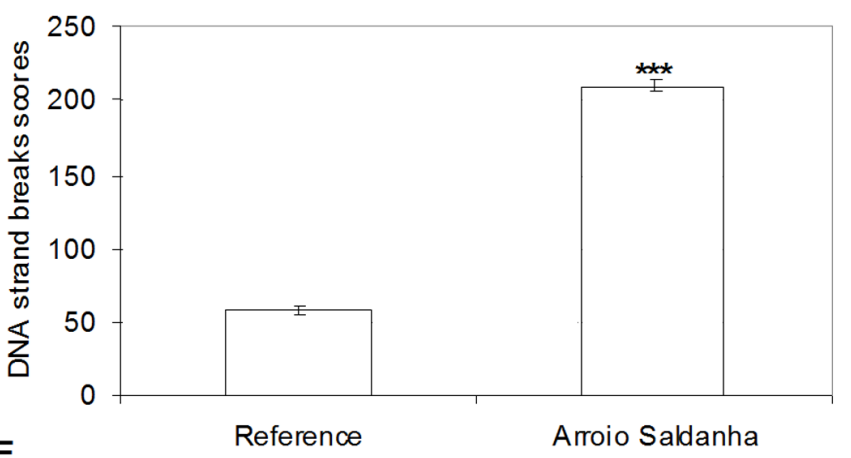

Higher levels of DNA damages (comet assay) were found in fishes from Arroio Saldanha (210.66 \pm 3.77$)$ compared to individuals from reference site (58 \pm 2.99$)$ (Fig. 3E). In individuals from Arroio Saldanha also the micronucleus test, showed higher values of NAs + MNs $(1.63 \pm 0.21)$ in relation with animals from reference site $(0.66 \pm 0.12)$ (Fig. 3F).

Histopathology revealed damages in both studied species (Table 3). In liver of $H$. reticulatus from Arroio Saldanha it was found eosinophilic centers (Fig. 4B) and neoplastic focus indicating a chronic exposure (Fig. 4C and 4D). Leukocytes infiltrations were also found (Fig. 4A). In gills, aneurysms, secondary lamellae disorganization, cellular proliferation and hypertrophy of branchial epithelium were found indicating acute exposure (Fig. 5B and 5D), and fusions in secondary lamellae (Fig. 5C) and secondary lamellae degeneration, indicating chronic exposure. Fig. 5A showed gills of animals from reference site.

No external anatomical alterations were found in individuals of $P$. caudimaculatus. Liver of adult $P$. candimaculatus
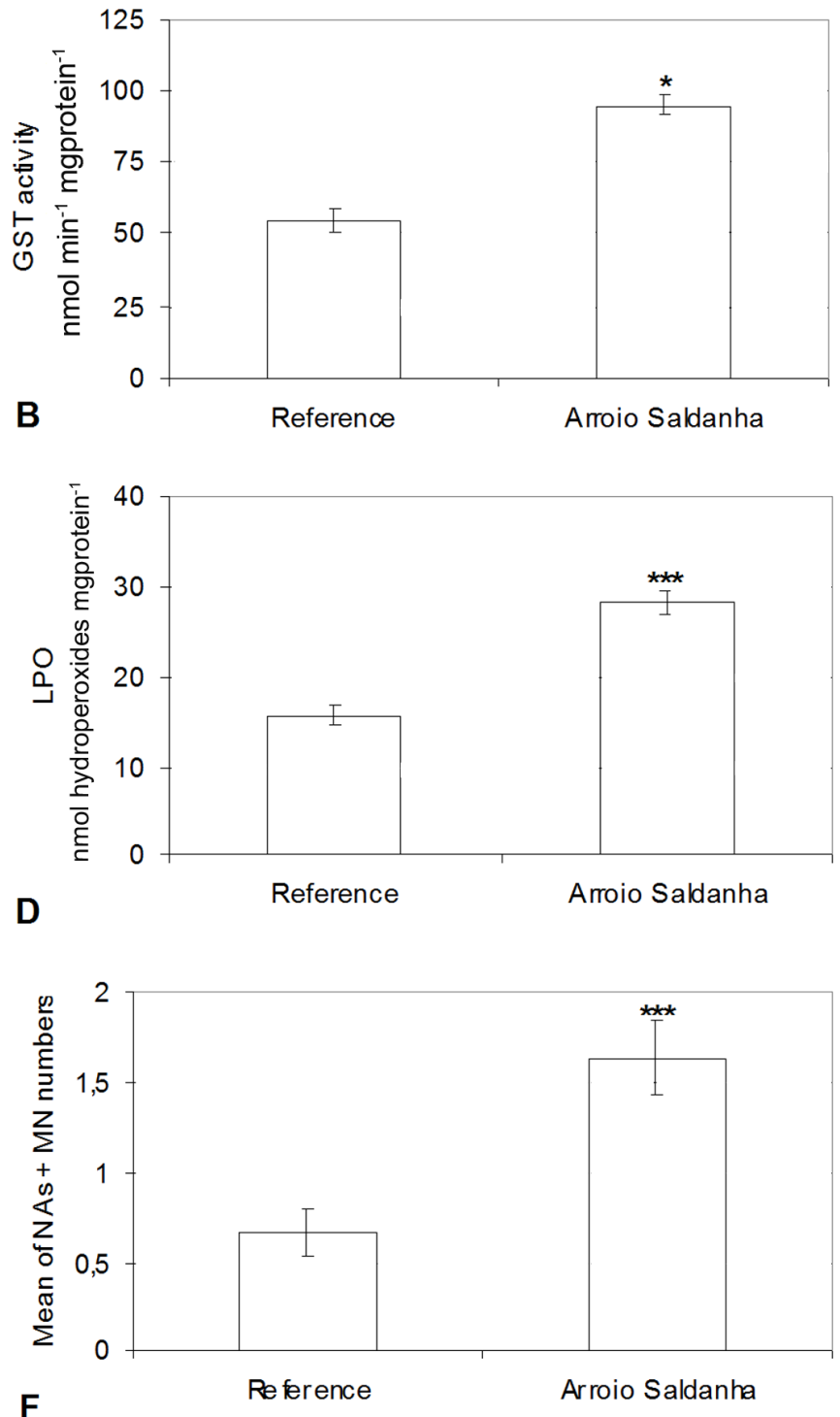

Figure 3 - Comparative biochemical and genotoxic findings in H. reticulatus from Arroio Saldanha and reference site. (A) ChE activity. (B) GST activity. (C) CAT activity. (D) Lipid Peroxidation. (E) Comet Assay. (F) Micronucleus Test. Bars $=$ mean \pm SE. $* \mathrm{P}<0.05$. *** $\mathrm{P}<0.001$. 
Table 3 - Occurrence of lesions found in liver and gills of $H$. reticulatus and $P$. caudimaculatus from Arroio Saldanha (light and scanning electron microscopy).

\begin{tabular}{|c|c|c|c|c|c|c|}
\hline \multirow[b]{3}{*}{ Lesions } & \multirow{2}{*}{\multicolumn{2}{|c|}{$\begin{array}{c}\begin{array}{c}\text { Hyphessobrycon } \\
\text { reticulatus }\end{array} \\
\text { Adults } \\
\end{array}$}} & \multicolumn{4}{|c|}{$\begin{array}{c}\text { Phalloceros } \\
\text { caudimaculatus }\end{array}$} \\
\hline & & & \multicolumn{2}{|l|}{ Adults } & \multicolumn{2}{|l|}{ Larvae } \\
\hline & Occurrence & $\%$ & Occurrence & $\%$ & Occurrence & $\%$ \\
\hline \multicolumn{7}{|l|}{ Liver } \\
\hline $\begin{array}{l}\text { Leukocyte } \\
\text { infiltrations }\end{array}$ & $5(30)$ & $16 \%$ & $6(15)$ & $40 \%$ & $2(53)$ & $3 \%$ \\
\hline Neoplastic foci & $2(30)$ & $6 \%$ & $1(15)$ & $6 \%$ & $0(53)$ & $0 \%$ \\
\hline $\begin{array}{l}\text { Eosinophilic } \\
\text { center (pre- } \\
\text { neoplastic foci) }\end{array}$ & $1(30)$ & $3 \%$ & $0(15)$ & $0 \%$ & $0(53)$ & $0 \%$ \\
\hline Necrosis & $0(30)$ & $0 \%$ & $7(15)$ & $46 \%$ & $0(53)$ & $0 \%$ \\
\hline $\begin{array}{l}\text { Cellular } \\
\text { Vacuolization }\end{array}$ & $0(30)$ & $0 \%$ & $4(15)$ & $26 \%$ & $2(53)$ & $3 \%$ \\
\hline $\begin{array}{l}\text { Melano- } \\
\text { macrophage } \\
\text { centers }\end{array}$ & $0(30)$ & $0 \%$ & $5(15)$ & $33 \%$ & & \\
\hline \multicolumn{7}{|l|}{ Gills } \\
\hline $\begin{array}{l}\text { Fusions in } \\
\text { secondary } \\
\text { lamellae }\end{array}$ & $8(30)$ & $26 \%$ & $7(15)$ & $46 \%$ & ne & ne \\
\hline $\begin{array}{l}\text { Secondary } \\
\text { lamellar } \\
\text { degeneration }\end{array}$ & $0(30)$ & $0 \%$ & $3(15)$ & $20 \%$ & ne & ne \\
\hline $\begin{array}{l}\text { Cellular } \\
\text { Proliferation } \\
\text { between } \\
\text { secondary } \\
\text { lamellae }\end{array}$ & $10(30)$ & $33 \%$ & $6(15)$ & $40 \%$ & ne & ne \\
\hline $\begin{array}{l}\text { Hypertrophy } \\
\text { of branchial } \\
\text { epithelium }\end{array}$ & $4(30)$ & $16 \%$ & $0(15)$ & $0 \%$ & ne & ne \\
\hline $\begin{array}{l}\text { Secondary } \\
\text { lamellar } \\
\text { degeneration }\end{array}$ & $1(30)$ & $3 \%$ & $0(15)$ & $0 \%$ & ne & ne \\
\hline $\begin{array}{l}\text { Secondary } \\
\text { lamellar } \\
\text { disorganization }\end{array}$ & $6(30)$ & $20 \%$ & $0(15)$ & $0 \%$ & ne & ne \\
\hline Aneurisms & $9(30)$ & $30 \%$ & $0(15)$ & $0 \%$ & ne & ne \\
\hline $\begin{array}{l}\text { Damages on } \\
\text { primary lamellae } \\
\text { surface }\end{array}$ & $0(30)$ & $0 \%$ & $4(15)$ & $26 \%$ & ne & ne \\
\hline Neoplasic foci & $0(30)$ & $0 \%$ & $4(15)$ & $26 \%$ & ne & ne \\
\hline
\end{tabular}
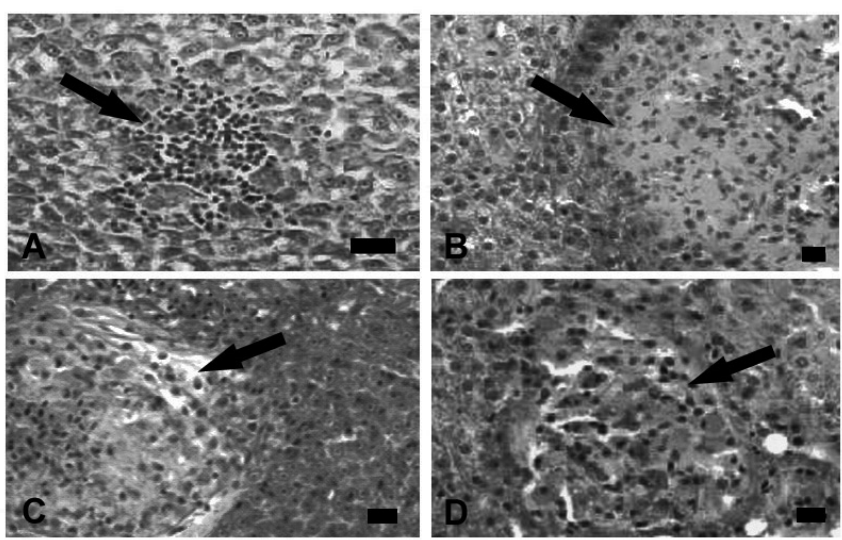

Figure 4 - Liver cross-section of H. reticulatus from Arroio Saldanha. HE stains. (A) leukocyte infiltration; (B) eosinophilic center; (C) (D) neplastic foci. Bars $=10 \mu \mathrm{m}$.

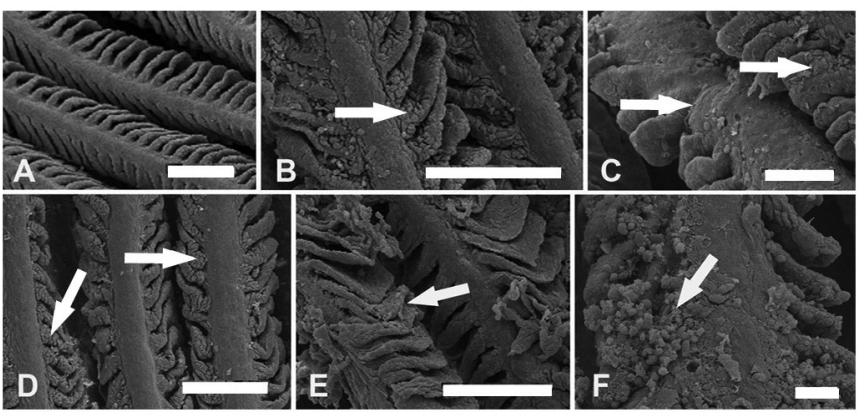

Figure 5 - Gills scanning electron microscopy of $H$. reticulatus from Arroio Saldanha. HE. (A) Normal aspect of gills; (B) (D) hypertrophy of branchial epithelium; (C) fusions between secondary lamellas; (E) secondary lamellae disorganization; (F) cellular proliferation between secondary lamellae. Bars $=100 \mu \mathrm{m}$

from Arroio Saldanha presented high incidence of severe pathological lesions as the occurrence of necrotic areas (Fig. 6B), inflammation with leucocytes infiltration, melanomacrophage centers (Fig. 6F) and cellular vacuolization (Fig. 6C and 6D). Other lesions as cellular hypertrophy (Fig. 6A) and neoplastic foci (Fig. 6E) were found in few individuals. In gills of adults $P$. caudimaculatus, the Fig. 7A shows the normal aspect of gills in animals from reference site and Fig. 7B and 7C show alterations as secondary lamellae fusion representing the most predominant lesion. Some alterations as the intense mucous release is also observed on primary lamellae surface (Fig. 7C). Low occurrence of cellular proliferation in primary lamellae, secondary lamellae degeneration and increase of mucous cells pores size were found.

In larvae of $P$. caudimaculatus, the spinal marrow, skin, retina, thymus, gill and pseudobranch did not present morphological damages. The liver in these specimens showed the same organization as described in adult individuals (Hybia, 1982; Rabitto et al., 2005), where polyhedral cells and a basophilic rounded nuclear shape of the hepathocytes were observed. Also the limit between hepathocyte was found as described to other teleostean species. Few individuals presented lesions in liver as cellular vacuolization and inflammatory response like leukocyte infiltration.

\section{DISCUSSION}

Despite of the limited chemical analysis the current results revealed and suggest that the sediment from Arroio Saldanha wetland is still highly contaminated by PAH's. It is know that other molecules nor PAH's can be found in sediment and also interpreted by fluorimetric method and without a GC/MS analysis this data is incomplete. But when associated with the chemical analysis in bile we can affirm that PAHs are still bioavaialable to fish evidencing the sediment as the most important source.

The predominance of 2-4-ring PAHs in the deepest cores of sediment indicates a petrogenic source of pollution, while the 5-6-ring PAHs on sediment surface indicates a pyrolytic source (Norta et al., 2001; Dahle et al., 2003; Olajire et al., 2005). The presence of pyrolytic PAHs on surface indicated 



Figure 6 - Liver cross-section of $P$. caudimaculatus from Arroio

Saldanha. HE stains. (A) Cellular hypertrophy; (B) necrosis; (C) (D) cellular vacuolization; (E) neoplastic foci; (F) melano-macrophage center. Bars $=10 \mu \mathrm{m}$
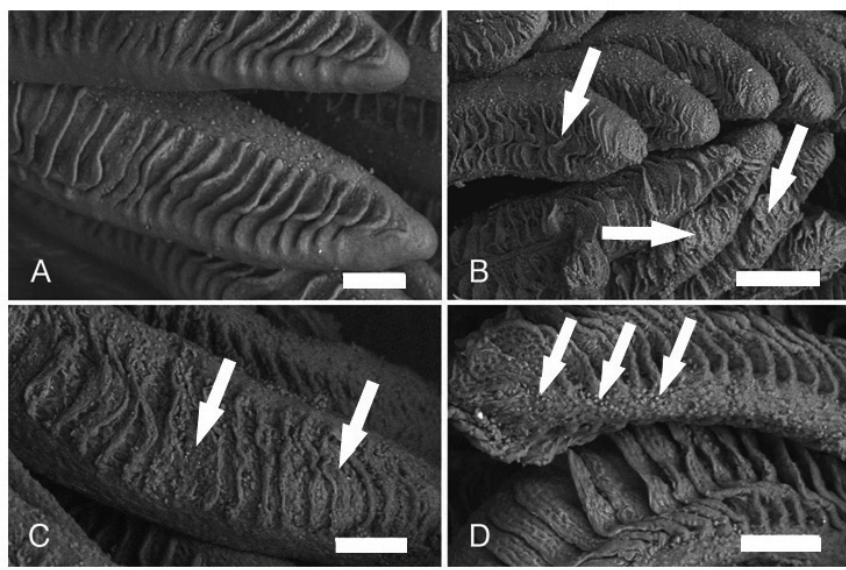

Figure 7 - Gills scanning electron microscopy of $P$. caudimaculatus from Arroio Saldanha. HE. (A) Normal aspect of gills; (B) secondary lamellae disorganization; (C) secondary lamellae fusions; (D) damages on primary lamellae surface. Bars $=100 \mu \mathrm{m}$.

a deposition of hydrocarbons by industrial activities. The important levels of petrogenic PAHs found in deepest layers could be related to Getulio Vargas oil spill, although other sources of contamination can not be discarded. The absence of 2-4-ring PAHs on superficial layers could be due to the lower stability of these compounds. Previous studies demonstrated that 2-4-ring PAHs are fast degraded in sediments (Jones et al., 1986). According to Zoest \& Van den Hurk (1990) the volatilization, photodegradation and biological mediation can also remove some of these compounds from sediment surface. Present data suggest that the PAHs found in the sediment are characterized by both pyrolytic and petrogenic inputs.

Hydrocarbons found in bile of Astyanax $s p$. confirm that PAHs presented in Arroio Saldanha's water are bioavailable.
These findings confirm the use of biliary PAHs metabolites contents as an efficient biomarker of exposure to fish, as described by others (Leadly et al., 1999; Lin et al., 2001; Yang et al., 2003). Camus et al. (1998) found PAHs metabolites in bile of Scophthalmus maximus after 24 hours of exposure to crude oil increasing the values until 4 days, and van den Hurk et al. (2006) described the presence of benzo(a)pyrene (BaP) after 48 hours of waterborne exposure in Ictalurus punctatus. The results of the current work show the bioavailability of PAHs present in the aquatic environment of Arroio Saldanha that could be related to a release of residual oil from sediment even after approximately 5 years of the accident. The bile chemical results indicated that PAHs are available for the native stream species, supporting the toxic effects described to $H$. reticulatus and $P$. caudimaculatus. These data demonstrate the continuous absorption of 2-6-rings PAHs by aquatic organisms probably available dissolved in water or available in food chain is even a potential risks to the ecosystem found in Arroio Saldanha water. Recently Silva et al. (2006) described experimentally the bioavailability of PAH's in Barigui River water, closed to the accident area. This river present high industrial and urban impact and also were found the bioavailability of PAH's and also metals.

Despite of the ChE inhibition has been more frequently related to organophosphate insecticides and carbamate (Oliveira Ribeiro et al., 2006) the absence of agriculture activities in the Arroio Saldanha wetland eliminated any possibility of this finding be related with pesticides exposure. According to other $\mathrm{ChE}$ is also inhibited by some toxic metals (Payne et al., 1996; Guilhermino et al., 1998; Cajaraville et al., 2000; Rabitto et al., 2005; Alves Costa et al., 2007), that can corroborated with the presence of oil once metals are frequently associated with oil composition. Otherwise, as verified in the present work the inhibition of $\mathrm{ChE}$ means also be related to crude oil exposures as described by RodríguezFuentes \& Gold-Bouchot (1999) and Akaishi et al. (2004). Organic compounds are also related with an activation of antioxidant enzymes as GST, GPx, GSH and CAT. That increase in enzymatic activity was observed to GST in the present work. GST activation was also observed for Carassius auratus (Zhang et al. 2004) and for Oreochromis mossambicus (Shailaja \& D'Silva 2003) exposed to different fractions of PAHs. Despite of this, no differences in CAT activity were observed among individuals from both studied sites. A possible explanation is that an activation of glutathione peroxidase (GPx) or other compensatory mechanisms not investigated in the current work could compensate the role of CAT in $H$. reticulatus. Another possible reason is that the presence of other contaminants not investigated in chemical analysis (e.g. heavy metals also presented in the oil composition) could be inhibiting the CAT activity.

A well known effect of organic compounds is the lipid peroxidation (Cossu et al., 1997; Shi et al, 2005; Barron et al, 2005; Almroth et al. 2005). Free radicals can react with nucleic acids and biological membranes rich in polyunsaturated fatty acids, resulting in increase of LPO (Halliwell \& Gutteridge, 
1984; Livingstone et al., 2000). An increase in lipid peroxidation was found in fishes from Arroio Saldanha. An LPO increase caused by PAHs can indicate induction in ROS production and an increase in enzyme activities as GST. These findings support the evidences that the fish populations from Arroio Saldanha exposed to PAHs, are under continuously effect of oxidative stress. The presence of ROS has been also associated with DNA damages (Marnett, 1999). Frenzilli et al. (2004) found DNA damage directly associated with LPO in Göteborg Harbor. Another genotoxic effect observed was the formation of $\mathrm{MN}$ and the prevalence of NAs in fishes from Arroio Saldanha. Although the mechanisms of $\mathrm{MN}$ and NA formation are not completely elucidated, studies have indicated a positive correlation between its appearance and the exposure to genotoxic contaminants (Tolbert et al., 1992; Serrano-Garcia \& Montero-Montoya, 2001). The increases of NA levels observed in $H$. reticulatus in the current work were also described by Venier et al. (1997), and an apparent specific lobed nuclei induction were related to fish exposed to petroleum refinery effluents (Çavas \& Ergene-Gözükara, 2005). The genotoxic effects observed in individuals from Arroio Saldanha, support the hypothesis that the presence of ROS is responsible for fatty acid oxidative damages, possibly affecting the DNA repair system and resulting in the maintenance of some unrepaired DNA breaks. As indicated, the cell's antioxidant defense systems were not efficiently enough, resulting directly in damages to DNA and lipid membranes, as observed in fishes from Arroio Saldanha compared with control group. These statements were previously indicated as a positive correlation between DNA strand breaks and PAHs, when aquatic organisms are chronically exposed (Mitchelmore et al. 1998; Cotelle \& Férard, 1999; Large et al., 2002).

Histopathological findings, when analyzed together with biochemical endpoints, facilitate the observation of the physiological response in individuals, thereby establishing a more realistic diagnosis for evaluating environmental health (Akaishi et al., 2004). In the present work we have showed lamellar fusions of secondary lamellae suggesting an acute exposure, also described by Çavas \& Ergene-Gözükara (2003) in Oreochromis niloticus exposed to petroleum refinery effluents. This kind of lesion can lead to a total fusion of secondary lamellae reducing the capacity for gas exchange. Branchial alterations as aneurysms, cellular proliferation between secondary lamellas and lamellar fusion found in individuals from Arroio Saldanha were also described in organisms exposed to petroleum compounds (Spies et al., 1996; Akaishi et al., 2004; Nero et al., 2006; Oliveira Ribeiro et al., 2005). In addition, Rudolph et al. (2001) observed in Onchorhynchus mykiss exposed to PAHs the presence of branchial epithelium hypertrophy also described by Çavas \& Ergene-Gözükara (2003) in the same species exposed to refinery effluents. These lesions were also observed in $H$. reticulatus and are associated with chronic exposure (Oliveira Ribeiro et al., 2005). In liver, the occurrence of leukocyte infiltrations in $H$. reticulatus indicates an inflammatory response or an immune susceptibility to external opportunist organisms as virus, bacteria or parasites.
Due to the potential carcinogenicity of PAHs (Shailaja \& D'Silva, 2003) mainly after chronics exposures (Roche et al., 2002), the occurrence of neoplastic focuses and PAHs exposure has been strongly related (Myers et al., 1998). These damages were considered by Nuñez et al. (1991) as 'transitional lesions' between a focus of cellular alteration and a carcinoma, indicating the nature of diversion subcellular disturbances (Boorman et al., 1997; Vethaak \& Wester, 1996). In the present work, the occurrence of carcinogenic focus and the high indexes of DNA damages demonstrated by comet assay revealed a strong evidence of chronic exposure to residual oil in sediment. The neoplasms described to both studied species (H. reticulatus and $P$. caudimaculatus) reinforce the hypothesis of PAHs bioavailability in Arroio Saldanha streams even six years after the accident. The eosinophilic centers found in $H$. reticulatus from Arroio Saldanha were also considered as preneoplastic focuses (Hawkins et al., 1990).

According to Bickham et al. (2000), the constant exposure to pollutants on the genetic structure of natural populations, as in Arroio Saldanha, could lead to two probable consequences: the increase of genetic variability by the emergence of new mutations, or its reduction conducting to serious disturbs to population and community structure.

\section{CONCLUSIONS}

The current results suggest the persistence of residual oil in the Arroio Saldanha sediment five years after the oil spill. Today, twelve years after the accident no more studies were developed in the area and now the access it is forbidden by the Petrobras Oil Company. We strongly recommend a more accurate biological and chemical analysis to verify the real conditions of the ecosystem. The current studies show that these compounds are bioavailable and represent a constant source of exposure to aquatic organisms. Also the chemical data reveals the contamination by the accident and also suggests an input of contaminants by industrial activity. In addition, the biomarkers used demonstrated that the residual oil in sediment is related with lesions in different levels of biological organization in both studied species of fish used as sentinels. Summarizing, the residual oil found in the sediment of Arroio Saldanha due to the accident in 2000 is still bioavailable to biota of Arroio Saldanha even five years after the accident and nothing was investigated after to know if this condition are still present in the area.

\section{ACKNOWLEDGMENTS}

This work was supported by CT-PETRO/CNPq (Brazilian Agency for Science and Technology) and in part by CNRS (Centre National de la Recherche Scientifique - France)

for financial support, Municipality Environment Secretary of the Araucaria self-government for assistance and the Electron Microscopy Science Center of Federal University of Parana for technical support. 


\section{REFERENCES}

AAS, E., BEYER, I., GOKSØYR, A., 2000, Fixed wavelength fluorescence (FF) of bile as a monitoring tool for polyaromatic hydrocarbon exposure in fish: an evaluation of compound specificity, inner filter effect and signal interpretation. Biomarkers $5,9-23$.

AEBI, H., 1984, Catalase in vitro. Methods Enzymol., 105: 121126.

AKAISHI, F.M., SILVA DE ASSIS, H.C., JAKOBI, S.C.G., STJEAN, S., COUTERNAY, S.C., LIMA, E., WAGNER, A.L.R., SCOFIELD, A., OLIVEIRA RIBEIRO, C.A., 2004, Morphological and neurotoxicological findings in tropical freshwater fish (Astyanax sp.) after waterborne and acute exposure to water soluble fraction (WSF) of crude oil. Arch. Environ. Contam. Toxicol., 46: 244-253. http://dx.doi.org/ 10.1016/j.scitotenv.2006.10.005

ALMROTH, B.C., STURVE, J., BERGLUND, A., FÖRLIN, L., 2005, Oxidative damage in eelpout (Zoarces viviparus), measured as protein carbonyls and TBARS, as biomarkers. Aquat. Toxicol.,73: 171-180. http://dx.doi.org/10.1016/j. aquatox.2005.03.007

AL-SABTI, K., METCALFE, C.D., 1995, Fish micronuclei for assessing genotoxicity in water. Mutat. Res., 343: 121-135.

ALVES COSTA, J.R.M., MELA, M., SILVA DE ASSIS, H.C., PELLETIER, É., RANDI, M.A.F., OLIVEIRA RIBEIRO, C.A., 2007, Enzymatic inhibition and morphological changes in Hoplias malabaricus from dietary exposure to lead (II) or methylmercury. Ecotoxicol. Environ. Saf., 62: 82-88. http://dx.doi.org/10.1016/j. ecoenv.2006.03.013

BARRON, M.G., CARLS, M.G., SHORT, J.W., RICE, S.D., HEINTZ, R.A., RAU, M., DI GIULIO, R., 2005, Assessment of the phototoxicity of weathered Alaska North Slope crude oil to juvenile pink salmon. Chemosphere, 60: 105-110. http://dx.doi. org/10.1016/j.chemosphere.2004.12.006

BASTOS NETO, A.C., CAICEDO, N.L., MELO, C.L., 2001, Avaliação da Contaminação do lençol freático na área do ponto zero (Município de Araucária, Paraná). In: PETROBRAS, (Eds.), $2^{\circ}$ Seminário do Rio Iguaçu. PETROBRAS, Curitiba, pp. 90-93.

BICKHAM, J.W., SHABEG, S., HEBERT, P.D.N., CHIKHI, L., ATHWAL, R., 2000, Effects of chemical contaminants on genetic diversity in natural populations: implications for biomonitoring and ecotoxicology. Mutat. Res., 463: 33-51.

BOORMAN, G.A., BOTTS, S., BUNTON, T.E., FOURNIE, J.W., HARSHBARGER, J.C., HAWKINS, W.E., HINTON, D.E., JOKINEN, M.P., OKIHIRO, M.S., WOLFE, M.J., 1997, Diagnostic criteria for degenerative, inflammatory, proliferative nonneoplastic and neoplastic liver lesions in medaka (Oryzias latipes): consensus of a national toxicology programme pathology working group. Toxicol. Pathol., 25: 202-210.

BRADFORD, M., 1976, A rapid and sensitive method for the quantification of microgram quantities of protein utilizing the principle of protein-dye binding. Anal. Biochem., 72: 248-254.

CAJARAVILLE, M.P., BEBIANNO, M.J., BLASCO, J., PORTE, C., SARASQUETE, C., AND VIARENGO, A., 2000, The use of biomarkers to assess the impact of pollution in coastal environments of the Iberian Peninsula: A practical approach. Sci. Total Environ., 247: 295-311.

CAMUS L., AAS E. AND BØRSETH, J.F., 1998, EthoxyresorufinO-deethylase activity and fixed wavelength fluorescence detection of PAHs metabolites in bile in turbot (Scophthalmus maximus L.) exposed to a dispersed topped crude oil in a continuous flow system. Mar. Environ. Res., 46: 29-32.

CARLS, M.G., BABCOCK, M.M., HARRIS, P.M., IRVINE, G.V.,
CUSICK, J.A, RICE, S.D., 2001, Resistance of oiling in mussel beds after the Exxon Valdez oil spill. Mar. Environ. Res., 51: 167-190.

CARLS, M.G., HARRIS, P.M., RICE, S.D., 2004, Restoration of oiled mussels beds in Prince William Sound, Alaska. Mar. Environ. Res., 57: 359-376. http://dx.doi.org/10.1016/j. marenvres.2003.11.002

CARRASCO, K.R., TILBURY, K.L., MYERS, M.S., 1990, Assessment of the piscine micronucleus test as an in situ biological indicator of chemical contaminants effects. Can. J. Fish. Aquat. Sci., 47: 2123-2136.

ÇAVAS, T., ERGENE-GÖZÜKARA, S., 2003, Micronuclei, nuclear lesions and interphase silver-stained nucleolar organizer regions (AgNORs) as cyto genotoxicity indicators in Oreochromis niloticus exposed to textile mill effluent. Mutat. Res., 538: 8191.

ÇAVAS, T., ERGENE-GÖZÜKARA， S., 2005, Induction of micronuclei and nuclear abnormalities in Oreochromis niloticus following exposure to petroleum refinery and chromium processing plant effluents. Aquat. Toxicol., 74: 264-271. http:// dx.doi.org/10.1016/j.aquatox.2005.06.001

COSSU, C., DOYOTTE, A., JACQUIN, M.C., 1997, Gluthatione reductase, selenium dependent gluthatione peroxidase, gluthatione levels, and lipid peroxidation in freshwater bivalves, Unio tumidus, as biomarkers contamination in field studies. Ecotoxicol. Environ. Saf., 38: 122-131.

COTELlE, S., FÉRARD, J., 1999, Comet assay in genetic ecotoxicology: a review http://dx.doi.org/ 34: 246-255.

DAHLE, S., SAVINOV, V.M., MATISHOV, G.G., EVENSET, A., NAES, K., 2003, Polycyclic aromatic hydrocarbons (PAHs) in bottom sediments of the Kara Sea Shelf, Gulf of $\mathrm{Ob}$ and Yenisei Bay. Sci. Total Environ., 306: 57-71.

ELLMANN, G.L., COURTNEY, K.D., ANDREAS, V.J., AND FEATHERSTONE, R.M., 1961, A new and rapid colorimetric determination of acetylcholinesterase activity. Biochem. Pharmacol., 7: 88.

FRENZILLI, G., SCARCELLI, V., BARGA, I.D., NIGRO, M., FORLIN, L., BOLOGNESI, C., STURVE, J., 2004, DNA damage in eelpout (Zoarces viviparus) from Goteborg harbour. Mutat. Res., 552: 187-195.

FROESE, R., PAULY, D. (EDS), 2006, FishBase. World Wide Web electronic publication. http//:www.fishbase.org.

GERRY, J., 1977. Characoids of the world. T.F.H. Publications Inc., USA.

GODOY, M.P., 1975. Peixes do Brasil: sub-ordem Characoidei, bacia do rio Mogi-Guaçú. Franciscana, Piracicaba.

GUILHERMINO, L., BARROS, P., SILVA, M.C., SOARES, A.M.V.M., 1998, Should the use of inhibition of cholinesterases as a specific biomarker for organophosphate and carbamate pesticides be questioned? Biomarkers, 32: 157-163.

HALLIWELL, B., GUTTERIDGE, J.M.C., 1984, Oxygen toxicity, oxygen radicals, transition metals and disease. Biochem. J., 219: $1-14$.

HARVEY, J.S., LYONS, B.P., PAGE, T.S., STEWART, C., PARRY, J.M., 1999, An assessment of the genotoxic impact of the Sea Empress oil spill by the measurement of DNA adducts levels in selected invertebrate and vertebrate species. Mutat. Res., 441: 103-114.

HAWKINS W.E., WALKER, W.W., OVERSTREET, R.M., LYTLE, J.S., LYTLE, T.E., 1990, Carcinogenetic effects of some polycyclic aromatic hydrocarbons on the Japanese medaka and guppy in waterborne exposures. Sci. Total Environ., 94: 155167.

HEDDLE, J.A., 1973, A rapid in vivo test for chromossome damage. 
Mutat. Res., 18: 187-192.

HUGGET, R.J., STEGEMAN, J.J., PAGE, D.S., PARKER, K.R., WOODIN, B., BROWN, J.S., 2003, Biomarkers in fish from Prince William Sound and the Gulf of Alaska: 1999-2000. Environ. Sci. Technol., 37: 4043-4051. http://dx.doi.org/ 10.1021/es0342401

JEWETT, S.C., DEAN, T.A., WOODIN, B.R., HOBERG, M.K., STEGEMAN, J.J., 2002, Exposure to hydrocarbons 10 years after the Exxon Valdez oil spill: evidence from cytochrome P4501A expression and biliary FACs in nearshore demersal fish. Mar. Environ. Res., 54: 21-48.

JIANG, Z-Y., HUNT, J.V., WOLFF, S.P., 1992, Ferrous ion oxidation in the presence of xylenol orange for detection of lipid hydroperoxide in low density lipoprotein. Anal. Biochem., 202: 384-389.

JIANG, Z-Y., WOOLLARD, A.C.S., WOLFF, S.P., 1991, Lipid hydroperoxides measurement by oxidation of $\mathrm{Fe}^{2+}$ in the presence of xylenol orange. Comparison with the TBA assay and an iodometric method. Lipids, 26: 853-856.

JONES, D.M., ROWLAND, S.J., DOUGLAS, A.G., HOWELLS, S., 1986, An examination of the fate of Niggerian crude oil in surface sediments of the Humber estuary by gas chromatography and gas chromatographymass spectrometry. Environ. Anal. Chem., 24: 227-247.

KAMMERER, M., MASTAIN, O., LE DRÉAN-QUENECH'DU, S., POULIQUEN H., LARHANTEC, M., 2004, Liver and kidney concentrations of vanadium in oiled seabirds after the Erika wreck. Sci. Total Environ., 333: 295-301. http://dx.doi. org/10.1016/j.scitotenv.2004.05.014

KEEN, J.H., HABIG, W.H., JAKOBY, W.B., 1976, Mechanism for several activities of the glutathione S-transferases. J. Biol. Chem., 251: 6183-6188.

KHAN, R.A., NAG, K., 1993, Estimation of hemosiderosis in seabirds and fish exposed to petroleum. Bull. Environ. Contam. Toxicol., 50: 125-131.

LARGE, A.T., SHAW, J.P., PETERS, L.D., MCINTOSH, A.D., WEBSTER, L., CHIPMAN, J.K., 2002. Different levels of mussel (Mytilus edulis) DNA strand breaks following chronic field and acute laboratory exposure to polycyclic aromatic hydrocarbons. Mar. Environ. Res., 54: 493-497.

LEADLY, T.A., ARCAND-HOY, L.D., HAFFNER, G.D., METCALFE, C.D., 1999, Fluorescent aromatic hydrocarbons in bile as a biomarker of exposure or brown bullheads (Ameiurus nebulosus) to contaminated sediments. Environ. Toxicol. Chem., 18: 750-755.

LIN E.L.C., NEIHEISEL T.W., FLOTEMERSCH J., SUBRAMANIAN B., WILLIAMS D.E., MILLWARD M.R., CORMIER S.M., 2001, Historical monitoring of biomarkers of PAH exposure of brown bullhead in the remediated Black River and the Cuyahoga River, Ohio. J Great Lakes Res., 27: 191-198.

LIVINGSTONE, D.R., CHIPMAN, J.K., LOWE, D.M., MINIER, C., MiTCHELMORE, C.L., MOORE, M.N., PETERS, L.D., PIPE, R.K., 2000, Development of biomarkers to detect the effects of organic pollution on aquatic invertebrates: recent molecular, genotoxic, cellular and immunological studies on the common mussel (Mytilus edulis L.) and other mytilids. Int. J. Environ. Pollut., 13: 56-91.

LYONS, B.P., HARVEY, J.S., PARRY, J.M., 1997, An initial assessment of the genotoxic impact of the Sea Empress oil spill by measurement of DNA adducts levels in intertidal teleost Lipophrys pholis. Mutat. Res., 390: 263-268.

MARIGÓMEZ, I., SOTO, M., CANCIO, I., ORBEA, A., GARMENDIA, L., CAJARAVILLE, M.P., 2006, Cell and tissue biomarkers in mussel, and histopathology in hake and anchovy from Bay of Biscay after the Prestige oil spill (Monitoring Campaign 2003). Mar. Pollut. Bull., 53: 287-304. http://dx.doi. org/10.1016/j.marpolbul.2005.09.026

MARNETT, L.J., 1999, Lipid peroxidation-DNA damage by malondialdehyde. Mutat. Res., 424: 83-95.

MARTY, G.D., HOFFMANN, A., OKIHIRO, M.S., HEPLER, K., HANES, D., 2003, Retrospective analyses: bile hydrocarbons and histopathology of demersal rockfish in Prince William Sound, Alaska, after the Exxon Valdez oil spill. Mar. Environ. Res. 56, 569-584. http://dx.doi.org/10.1016/S0141-1136(03)00043-6

MARTY, G.D., OKIHIRO, M.S., BROWN, E.D., HANES, D., HINTON, D.E., 1999, Histopathology of adult pacific herring in Prince William Sound, Alaska, after the Exxon Valdez oil spill. Can. J. Fish. Aquat. Sci., 56: 419-426.

MENICONI, M.F.G., GABARDO, I.T., CARNEIRO, M.E.R., BARBANTI, S.M., SILVA, G.C., MASSONE, C.G., 2002, Brazilian oil spills chemical characterization - case studies. Environ. Forens., 3: 303-321.

MITCHELMORE, C.L., BIRMELIN, C., CHIPMAN, J.K., LIVINGSTONE, D.R., 1998, Evidence for cytochrome P450 catalysis and free radical involvement in the production of DNA strand breaks by benzo(a)pyrene and nitroaromatics in mussel (Mytilus edulis L.) digestive gland cells. Aquat. Toxicol., 41: 193-212.

MYERS, M., JOHNSON, L., HOM, T., COLLIER, T., STEIN, J., VARANASI, U., 1998, Toxicopathic hepatic lesions in subadult English sole (Pleuronectes vetulus) from Puget Sound, Washington USA: relationships with other biomarkers of contaminant exposure. Mar. Environ. Res., 45: 47-67.

NERO, V., FARWELL, A., LISTER, A., VAN DER KRAAK, G., LEE, L.E.J., VAN MEER, T., MACKINNON, M.D., DIXON, D.G., 2005, Gill and liver histopathological changes in yellow perch (Perca flavescens) and goldfish (Carassius auratus) exposed to oil sands process-affected water. Ecotoxicol. Environ. Saf., 63: 365-377. http://dx.doi.org/10.1016/j.ecoenv.2005.04.014

NORTA, M., LESKOVSEK, H., FAGANELI, J., 2001, Composition, distribution and sources of polycyclic aromatic hydrocarbons in sediments of the Gulf of Trieste, Northern Adriatic Sea. Mar. Pollut. Bull., 42: 36- 44.

NUÑEZ, O., HENDRICKS, J.D., DUIMSTRA, J.R., 1991, Ultrastruture of hepatocellular neoplasms in aflatoxin B1 (AFB1)initiated rainbow trout (Oncorhynchus mykiss). Toxicol. Pathol., 19: 11-23.

OLAJIRE, A.A., ALTENBURGER, R., KQSTER, E., BRACK, W., 2005, Chemical and ecotoxicological assessment of polycyclic aromatic hydrocarbon - contaminated sediments of the Niger Delta, Southern Nigeria. Sci. Total Environ., 340: 123-136. http://dx.doi.org/10.1016/j.scitotenv.2004.08.014

OLIVEIRA RIBEIRO, C.A., VOLLAIRE, Y., SANCHEZCHARDI, A., ROCHE, H., 2005, Bioaccumulation and the effects of organochlorine pesticides, PAH and heavy metals in the Eel (Anguilla anguilla) at the Camargue Nature Reserve, France. Aquat. Toxicol., 74: 53-69. http://dx.doi.org/ 10.1016/j. aquatox.2005.04.008

PAYNE, J.F., MATHIEU, W., MELVIN, W., FANCEY, L.L., 1996, Acetylcholinesterase, an old biomarker with a new future? Field trials in association with two urban rivers and a paper mill in Newfoundland. Mar. Poll. Bull., 32: 225-231.

PEDROZO, M.F.M., BARBOSA, E.M., CORSEUIL, H.X., SCHENEIDER, M.R., LINHARES, M.M. (EDS.), 2000, Ecotoxicologia e avaliação de risco do petróleo. Série cadernos de referência ambiental, Salvador.

PIETRAPIANA, D., MODENA, M., GUIDETTI, P., FALUGI, C., VACCHI, M., 2002, Evaluating the genotoxic damage and 
hepatic tissue alterations in demersal fish species: A case study in the Ligurian Sea (NW-Mediterranean). Mar. Pollut. Bul., 44: 238-243.

PORTE, C., BIOSCA, X., SOlÉ, M., AlBAigÉS, J., 2000, The Aegean Sea oil spill on the Galician coast (NW Spain). III. The assessment of long-term sublethal effects on mussels. Biomarkers, 5: 436-444.

RABITTO, I.S., ALVES COSTA, J.R.M., SILVA DE ASSIS, H.C., PELLETIER, E., AKAISHI, F.M., ANJOS, A., RANDI, M.A.F., OLIVEIRA RIBEIRO, C.A., 2005, Effects of dietary $\mathrm{Pb}$ (II) and tributyltin on neotropical fish, Hoplias malabaricus: histopathological and biochemical findings. Ecotoxicol. Environ. Saf., 60: 147-156. http://dx.doi.org/ 10.1016/j. ecoenv.2004.03.002

ROCHE, H., BUET, A., RAMADE, F., 2002, Accumulation of lipophilic microcontaminants and biochemical responses in Eels from the Camargue biosphere reserve. Ecotoxicology, 11: 155164.

RODRÍGUEZ-FUENTES， G., GOLD-BOUCHOT, G., 1999, Environmental monitoring using acetylcholinesterase inhibition in vitro. A case study in two Mexican lagoons. Mar. Environ. Res., 50: 357-360.

RUDOLPH, A., YANEZ, R., TRONCOSO, L., 2001, Effects of exposure of Onchorhynchus mykiss to the water accomodated fraction of petroleum hydrocarbons. Bull. Environ. Contam. Toxicol., 66: 400-406.

SCHMID, W., 1975, The micronucleus test. Mutat. Res., 31: 9-15.

SERRANO-GARCIA, L., MONTERO-MONTOYA, R., 2001. Micronuclei and chromatine buds are related genotoxic events. Environ. Mol. Mutagen. 38, 38-45.

SHAILAJA, M.S., D’SILVA, C., 2003, Evaluation of impact of PAH on a tropical fish. Oreochromis mossambicus using multiple biomarkers. Chemosphere, 53: 835-841. http://dx.doi. org/10.1016/S0045-6535(03)00667-2

SHI, H., SUI, Y., WANG, X., LUO, Y., JI, L., 2005, Hydroxyl radical production and oxidative damage induced by cadmium and naphthalene in liver of Carassius auratus. Comp. Biochem. Physiol., 140: 115-121. http://dx.doi.org/10.1016/j. cca.2005.01.009

SILVA, C., OLIVEIRA RIBEIRO, C.A., KATSUMITI, A., ARAUJO, M.L.P., ZANDONA, E.M., COSTA SILVA, G.P., MASCHIO, J., ROCHE, H., SILVA DE ASSIS, H.C., 2009, Evaluation of waterborne exposure to oil spill 5 years after an accident in Southern Brazil. Ecotoxicol. Environ. Safety., 72: 400-409. http://dx.doi.org/10.1016/j.ecoenv.2008.03.009

SILVA DE ASSIS, H.C., 1998, Der Einsatz von biomarkern zur summarischen erfassung von gewässerverschmutzungen. Thesis presented at Technical University of Berlin, Germany.

SINGH, N.P., MCCOY, M.T., TICE, R.R., SCH, E.L., 1988, A simple technique for quantitation of low levels of DNA damage in individual cells. Exp. Cell Res., 175: 184-191.

SOLÉ, M., PORTE, C., BIOSCA, X., MITCHELMORE, C.L., CHIPMAN, J.K., LIVINGSTONE, D.R., ALBAIGÉS, J., 1996, Effects of the "Aegean Sea" oil spill on biotransformation enzymes, oxidative stress and DNA-adducts in digestive gland of the mussel (Mytilus edulis L.). Comp. Biochem. Physiol. C, 13: 257-265.

SPIES, R.B., STEGEMAN, J.J., HINTON, D.E., WOODIN, B., SMOLOWITZ, R., OKIHIRO, M., SHEA, D., 1996, Biomarkers of hydrocarbon exposure and sublethal effects in embiotocid fishes from a natural petroleum seep in the Santa Barbara channel. Aquat. Toxicol., 34: 195-219.

TOLBERT, P.E., SHY, A.C., ALLEN, J.W., 1992, Micronuclei and other nuclear abnormalities in buccal smears: methods development. Mutat. Res., 271: 69-77.

VAN DEN HURK, P., 2006, Bile fluorescence, heme oxygenase induction, and increased biliverdin excretion by mixtures of environmental toxicants. Aquat. Toxicol., 77: 202-209. http:// dx.doi.org/10.1016/j.aquatox.2005.12.004

VENIER, P., MARON, S., CANOVA, S., 1997, Detection of micronuclei in gill cells and haemocytes of mussels exposed to benzo(a)pyrene. Mutat. Res., 390: 33-44.

VETHAAK, A.D., WESTER, P.W., 1996, Diseases of flounder Platichthys flesus in Dutch coastal and estuarine waters, with particular reference to environmental stress factors. II. Liver histopathology. Dis. Aquat. Organ., 26: 99-116.

YANG X.A., PETERSON D.S., BAUMANN P.C., LIN E.L.C., 2003, Fish biliary PAH metabolites estimated by fixed-wavelength fluorescence as an indicator of environmental exposure and effects. J. Great Lakes Res., 29: 116-123.

ZAWADZKI, C.H., RENESTO, E., BINI, L.M., 1999, Genetic and morphometric analysis of three species of the genus Hypostomus, Lacépèdes, 1803 (Osteichthyes: loricariidae) from the Rio Iguaçú basin (Brazil). Rev. Suisse Zool., 106: 91-105.

ZHANG, J.F., WANG, X.R., GUO, H.Y., WU, J.C., XUE, Y.Q., 2004, Effects of water-soluble fractions of diesel oil on the antioxidant defenses of the goldfish, Carassius auratus. Ecotoxicol. Environ. Saf., 58: 110-116. http://dx.doi. org/10.1016/j.ecoenv.2003.08.025

ZOEST, R., VAN ECK, G.T.M., 1990, Behaviour of particulate polychlorinated biphenyls and polycyclic aromatic hydrocarbons in the Scheldt Estuary, Netherlands. J. Sea Res., 26: 89-96. 